\title{
The effects of olfactory bulb lesions on the maternal behavior of the mouse
}

\author{
J. J. COWLEY and A. J. COOPER \\ The Queen's University, Belfast, Northern Ireland
}

\begin{abstract}
Two experiments are described. Mice bulbectomized during pregnancy failed to care for their offspring and built poorly constructed nests. Lesions placed 2 days after parturition, of comparable size, did not prevent the mothers from caring for their litters, though the young were lighter than controls after 7 days. Bulbectomized lactating females were more active than controls when first returned to their home cages. They failed to retrieve their young and initially demolished their nests, although these were later found to be as well formed as those of controls.
\end{abstract}

In mice, removal of the olfactory bulbs prior to parturition disrupts the expression of maternal behavior. Typically, the mice cannibalize the babies and there is little evidence of nest building and other activities associated with the care of the young (Gandelman, Zarrow, Denenberg, \& Myers, 1971). That the behavior of the mice is not entirely dependent on the hormonal changes associated with pregnancy is supported by the finding that bulbectomized adult virgin female mice also show the cannibalistic behavior and little nest building or other behavior associated with caring for the young (Gandelman et al., 1971). Normally, however, a wide spectrum of maternal behavior can be elicited from the virgin female mice following their exposure to the presence of infant mice. The younger the baby, the more effective it is in eliciting the behavior (BeniestNoirot, 1958; Noirot, 1964). The observations on the effects of bulbectomy during pregnancy have been extended to the mothers' behavior during lactation (Gandelman, Zarrow, \& Denenberg, 1971). Again the mothers cannibalize the new born, though the incidence of infanticide was found to decrease as the age of the young increased. The acquisition of adult characteristics, particularly fur, coincides with the ending of the cannibalism. Under normal conditions the odor of the newborn may act to inhibit the cannibalism during the first few days of life and the absence of olfactory cues, after bulbectomy, may promote the killing.

Our own work has centered on the effects of bulbectomy early in life on the growth and development of mice. During the course of this work, it was observed that female mice with lesions restricted to the lateral regions of the bulb ate or scattered their young about the nest; mice with lesions confined to the central region did not do so, and the infant mortality was the same as that of control operated mice (McClelland \&

J. J. Cowley is now at the School of Natural Sciences (Psychology), Hatfield Polytechnic, Hatfield, Herts, United Kingdom. A. J. Cooper is at the Department of Psychology, Miami University, Oxford, Ohio.
Cowley, 1973). The mice were lesioned 5 days after birth and mated at 80 days of age; the results show that the effects are permanent and that the localization of the lesion may have a differential effect on the mother's behavior.

The present study examines the effects of bilateral lesions of the anterior pole of the bulbs in multiparous female mice during pregnancy and lactation on the responsiveness of the mice to their offspring during the first postpartum week. The lesions were restricted to the rostral end of the bulbs to reduce the chances of damage to the frontal cortex and anterior olfactory nucleus, though in the first experiment a sample of mice with "total" bulbectomy was included.

\section{METHOD}

\section{Experiment 1: Bulbectomy During Pregnancy}

The subjects were 23 mature multiparous female mice from the Department colony. The mice originally derived from an inbred strain (Carworth Farm Mice, CF 1) were later outbred and subsequently referred to as CS 1 . The mice were operated on 11-14 days after they had mated (determined by the presence of vaginal plug) and randomly assigned to one of three treatments. The olfactory bulbs of eight mice were entirely removed (total bulbectomy), while another seven mice had only the anterior portions of both bulbs removed (anterior bulbectomy). A third sample of eight mice (control operated) underwent the same operative procedure but no olfactory tissue was removed. All operations were carried out under sodium pentobarbital anesthesia. A longitudinal midline incision was made in the skin overlying the frontal bones and burr holes drilled on either side of the midline to expose the bulbs, which were aspirated with a bevelled hypodermic needle (Size 15) attached to a suction tube and filter pump. After bleeding had stopped, the skin was sutured and thereafter the mice were housed individually in Makralon cages $(28 \times 21.5 \times 10 \mathrm{~cm}$ high). A thin layer of Irish peat moss covered the floor of the cage. The mice were housed in an artificially lit room with a 12-h light cycle (lights on $0800 \mathrm{~h})$ and maintained at constant temperature $\left(21^{\circ} \mathrm{C}\right)$. Food (Diet 41B; Bruce, 1950) and water were available at all times. Everyday, from the day on which the mice were operated, they were given a single two-ply tissue (Kleenex laboratory tissues) and an assessment was made on a five-point scale of the degree of insulation that the nest afforded, a high score being given to a well insulated nest and a low score to one which was flat and without a roof or walls. The litters were examined daily 
and a record kept of the number of surviving young. As nearly all the offspring were cannibalized by the mothers in the bulbectomized samples, no indices of maternal behavior, other than nest building, were recorded in this experiment.

\section{Experiment 2: Bulbectomy During Lactation}

The multiparous mice were from the same strain and stock as those used in Experiment 1. The lactating mothers and their litters were randomly divided into two treatments 2 days after they had littered (Day $0=$ day of birth). Six babies were assigned to each mother. The anterior poles of the olfactory bulbs were removed from eight of the mothers, the procedure being the same as in the previous experiment. The second half of the sample $(\mathrm{N}=8)$ underwent the control operation. While the mothers underwent surgery, their litters were kept in their nests in a constant-temperature oven $\left(33^{\circ} \mathrm{C}\right)$. After the females had completely recovered from the effects of the anesthetic (5-6 h), they were returned to their litters, and their behavior was recorded over a $30-\mathrm{min}$ period. Prior to the mother's return to her cage, one of the young and a pellet of food were placed in opposite corners of the cage, on the side remote from the nest. The following measures were taken: (1) Activity-it was noted whether any locomotion occurred during each of the 30 1-min intervals. (2) Hyperactivity-it was noted whether the mouse, on being returned to the cage, displayed darting movements. The movements were often accompanied by a fleeting inspection of objects in the cage and indiscriminate walking through the nest. (3) Time in nest-the number of complete 1 -min periods during which the mouse was in its nest was recorded. (4) Latency to settle-the time taken for the mouse to settle down in the nest was also recorded. An arbitrary criterion of $1 \mathrm{~min}$ in the nest was taken as evidence of settling. (5) Retrieval of young-the time taken for the mother to retrieve the pup to the nest was recorded. (6) Response to food-the number of occasions that the mouse nibbled the food pellet during the 30-min time period was noted.

Growth and mortality of the young. Each day, for 7 days, the litters were weighed and examined. On the day after the removal of the bulbs, the quality of the nest was rated on the same scale as that used in Experiment 1. The Kruskal-Wallis analysis of variance and Mann-Whitney U tests (Siegel, 1956) were used in determining $p$ values, unless otherwise stated.

\section{RESULTS}

\section{Experiment 1}

The lesioned animals did not lose weight and they gave birth at the expected time (18th day of gestation). (1) Infant mortality: Total bulbectomy and anterior bulbectomy were associated with a high incidence of cannibalism, usually within $24 \mathrm{~h}$ after birth. In only two litters, one from each treatment, did any babies survive to 7 days of age. There were no deaths in the litters of control operated mice. (2) Nest building: Both bulbectomized groups built nests rated inferior to those of controls ( $p<.001$ in both cases), but the anterior bulbectomy group built nests rated superior to those of the total bulbectomy group $(p<.05)$.

\section{Experiment 2}

The results, summarized in Table 1 show marked short-term behavior differences between bulbectomized and control operated mice. The bulbectomized mice were more active than the controls. Both groups showed active exploration when first returned to their cage, but this decreased after about $10 \mathrm{~min}$ in the control operated group only. Hyperactivity was observed in only one control mouse and lasted for less than $1 \mathrm{~min}$. Five of the eight bulbectomized mice were hyperactive; in one case, this agitated behavior persisted for $8 \mathrm{~min}$ $\left(\chi^{2}=4.96, p<.05\right)$. The control mice spent more time in the nest and took less time to settle with their litters (latency) than did the lesioned mice, whose nests were frequently demolished as a result of their hyperactivity. None of the bulbectomized mice retrieved the babies during the $30-\mathrm{min}$ observation period, whereas all the control mice did, usually within the first minute after being returned to the cage $\left(\chi^{2}=16, p<.001\right)$. Most of the bulbectomized mice were observed to inspect the baby, but none attempted to carry it to the nest. The pellet of food was nibbled more frequently by the bulbectomized mothers, although we did not measure the food consumption of these animals.

All the litters of the control sample and all but one of the bulbectomized animals' litters survived to Day 7, at which time the experiment was discontinued. The litters of the bulbectomized animals grew more slowly; the weight difference between the bulbectomized and the control litters was significant by Day $7(p<.05)$. Finally, nest quality was rated as in the first experiment. The nests of the bulbectomized mice, though often initially destroyed, were rated slightly superior (although not significantly so) to those of the controls throughout the experiment (see Table 1).

Examination of brains. Following behavioral observations, the mice were killed and their brains fixed in $10 \%$ formalin solution. An estimate of the extent of bulbectomy (percent bulbectomy) was made in the following way: Each brain was placed on an overhead

Table 1

Growth and Behavioral Changes in Bulbectomized and Control-Operated Mice

\begin{tabular}{|c|c|c|c|c|}
\hline \multirow[b]{2}{*}{ Behavior } & \multicolumn{2}{|c|}{ Mean Score } & \multirow[b]{2}{*}{$\begin{array}{c}\text { Mann-Whitney } \\
\text { U Test }\end{array}$} & \multirow[b]{2}{*}{$\mathbf{p}$} \\
\hline & $\begin{array}{c}\text { Bulbectomized } \\
\text { Mice* }\end{array}$ & $\begin{array}{c}\text { Control Operated } \\
\text { Mice* } \\
\end{array}$ & & \\
\hline Activity & 18.6 & 8.4 & 5 & $<.001$ \\
\hline Time in nest (minutes) & 5.0 & 19.5 & 3.5 & $<.001$ \\
\hline Latency to settle (minutes) & 15.8 & 7.9 & 5 & $<.05$ \\
\hline Food pellet contact (frequency) & 9.1 & 3.1 & 15.5 & $<.05$ \\
\hline Nest rating (postoperative) & 4.5 & 3.6 & 17 & n.s. \\
\hline Mean weight of pups 7 days postoperative (grams) & 4.46 & 5.05 & 14.5 & $<.05$ \\
\hline
\end{tabular}

${ }^{*} N=8$ 
projector so that its shadow was cast on a screen overlaid with graph paper (1-mm squares). The olfactory bulb area was estimated, from both dorsal and ventral sides, and the formula: [100 X (mean area of bulbs of control mice - mean area of bulbs remaining) $\div$ (mean area of bulbs of control mice)] determined percent bulbectomy. All of the "total bulbectomy" mice of Experiment 1 were found to have had all their olfactory bulbs removed; five of the eight had additional slight damage to the anterior frontal lobes. The anterior bulbectomy group had a mean of $65 \%$ of their bulbs removed; damage was, in general, about equal on each side; there was no cortical involvement. In Experiment 2 bulbectomized animals sustained a mean $67 \%$ bulbectomy, again with generally equal damage bilaterally and no cortical involvement.

\section{DISCUSSION}

Both total and anterior-restricted olfactory bulb lesions to mice during the latter half of pregnancy result in cannibalism of the young; these findings are in accordance with those of Gandelman et al. (1971). As reported by Zarrow, Gandelman, and Denenberg (1971), bulbectomized mice built nests inferior to those of controls, but a relationship between lesion magnitude and nest complexity is suggested by the superiority of nests of the anterior lesion group over those of totally bulbectomized animals.

Only one anterior lesioned lactating mouse cannibalized its litter, a result at variance with that of Gandelman et al. (1971). The slower growth of the offspring of these mice may indicate a hormonal change resulting in lowered milk secretion; in view of widespread influences exerted by olfactory centers on hypothalamic and other limbic structures, such an effect would not be surprising. The hyperactivity which characterized the bulbectomized animals might also be associated with changes in maternal behavior. Bulbectomized mice initially destroyed their nests by running through and over them, were slower to settle with their litters, and failed to retrieve the young during the observation period. They paid brief attention to the baby and inspected the food pellet in the same fleeting manner.

The interpretation of behavioral changes following bulbectomy is not straightforward. Mice with anterior bulb lesions show impaired olfactory acuity; they fail to discriminate by smell between foodcups containing samples of their diet and cups containing food/sawdust mixtures, a discrimination readily made by controls (Cooper, Note 1 ). We do not consider, however, that the behavioral changes found in this study are entirely due to changes in olfactory sensitivity. Similar sized lesions produced a very different response in pregnant as opposed to postparturient mice, suggesting the establishment of lactation as a factor reducing the infanticide. Experiential and hormonal factors have been implicated in the disruption of maternal behavior which follows bulbectomy in rats (Schlein, Zarrow, Cohen, Denenberg, \& Johnson, 1972), but in the present study animals lesioned both during pregnancy and lactation had previously reared litters and the part played by experience is not readily apparent.

\section{REFERENCE NOTE}

1. Cooper, A. J. Some effects of olfactory bulb lesions on the development and behavior of male mice. $\mathrm{PhD}$ thesis, The Queen's University, Belfast, Northern Ireland, 1973.

\section{REFERENCES}

BenIEst-Norrot, E. Analyse du comportement dit "maternal" chez la souris. Centre National de la Recherche Scientifique, 1958. (Monographies Francaises de Psychologie 1).

BRUCE, H. M. Feeding and rearing of laboratory animals. Journal of Hygiene (Cambridge), 1950, 48, 171-183.

Gandelman, R., Zarrow, M. X., \& Denenberg, V. $\mathrm{H}$. Stimulus control of cannibalism and maternal behavior in anosmic mice. Physiology and Behavior, 1971, 7, 583-586.

Gandelman, R. ZarRow, M. X., Denenberg, V. H., \& MYERs, M. Olfactory bulb removal eliminates maternal behavior in the mouse. Science, 1971, 171, 210-211.

McClelland, R. J., \& Cowley, J. J. Olfactory bulb lesions and under-nutrition in neonatal mice. International Research Communication Systems: Medical Science, 1973, $1,12$.

NoIRor, E. Changes in responsiveness to young in the adult mouse: II. The effect of external stimuli. Journal of Comparative and Physiological Psychology, 1964, 57, 97-99.

Schlein, P. A., Zarrow, M. X., Cohen, H. A., Denenberg, V. H., \& Johnson, N. P. The differential effect of anosmia on maternal behavior in the virgin and primiparous rat. Journal of Reproduction and Fertility, 1972, 30, 139-142.

SIEGEL, S. Non-parametric statistics for the behavioral sciences. London: McGraw-Hill, 1956.

Zarrow, M. X., Gandelman, R., \& Denenberg, V. H. Lack of nest building and maternal behavior in the mouse following olfactory bulb removal. Hormones and Behavior, 1971, 2, 227-238.

(Received for publication August 26, 1976.) 